\title{
DISCRETIONARY BENEFITS AND EMPLOYEE RETENTION IN STATE AGENCIES: A CASE OF REGULATORY STATE AGENCIES UNDER THE NATIONAL TREASURY, NAIROBI CITY COUNTY, KENYA
}

\author{
${ }^{1}$ Sang Hilda Cheptoo $\$$ James Kilika \\ ${ }^{1}$ Department of Business Administration, Kenyatta University \\ Corresponding author's e-mail: sahilda@gmail.com
}

How to cite this article: Cheptoo, S., H. \& Kilika, J. (2021). Discretionary benefits and employee retention in state agencies. A case of regulatory state agencies under the national treasury, Nairobi City County, Kenya. Edith Cowan Journal of Strategic Management, 1(1), 10-18.

\section{ARTICLE INFO \\ Article history: \\ Received Date: $2^{\text {nd }}$ June 2021 \\ Revised Date: $14^{\text {th }}$ June 2021 \\ Accepted Date: $17^{\text {th }}$ June 2021}

\section{Keywords:}

Regulatory framework, ethical, compliance, preference,

reservation directive

\section{A B S T R A C T}

Purpose: Retention of employees in Kenya's state agencies has been cited as a big challenge that has continued to undermine effective and efficient service delivery to the public. Employee retention is key to these agencies and failure to retain employees significantly affects their operations thus having a great impact on their service delivery, sustainable development and contribution towards Vision 2030. This study explored the influence of discretionary benefits on employee retention in Kenya's state regulatory Agencies operating under the National Treasury.

Design/ Methodology/Approach: The study adopted descriptive and cross sectional research designs and 320 employees of the four regulatory state agencies under the National Treasury, Kenya, as at $30^{\text {th }}$ June 2017. Stratified proportionate simple random sampling was used in selecting a sample size of 175 with top, middle level management and support staff used as strata. Quantitative and qualitative primary data was collected using self-administered semistructured questionnaires. The study used both descriptive and inferential statistics to analyze the collected data.

Findings: The study found positive and significant relationship between three independent variables namely health insurance, wellness programs, and work life balance and the dependent variable which was employee retention. Pension plan was found to have an insignificant relationship with the employee retention.

Contribution to policy and practice: The study concluded that that the managers should craft strategies aimed at reducing attrition rates. Originality/Value: The study extends the literature on strategic human resource management. It is the first study to be conducted on employee retention in state agencies. 


\section{BACKGROUND}

Employee retention is inextricably linked with discretionary benefits, hence, the existence and features of benefits are major determinants of an organization's ability to attract and retain experienced and talented staff. As much as various covariates may be responsible for employee retention in developing countries, studies reveal that employee retention can be explained by well-known employee benefits (Whitaker, 2010). Employee retention is the ability of an organization to prevent its staff from exiting by winning their trust, liking, commitment, and loyalty. Retention is the will to identify, commit, trust and recommend other talented individuals to seek employment in such organizations. Paying at market rates or above is not sufficient to effectively manage talent and as Kwon (2013) notes, employers keen on retention of their employees design retention strategies such as work life balance, private healthcare, retirement plans and wellness. Whitaker (2010), Chiang and Birtch (2011), note that, benefits have the ability to improve the quality of employees' lives and help organization achieve, among others, motivation, positive culture, and loyalty of employees. Discretionary benefits especially those that are non-financial or indirect financial in nature have been used by employers as alternative rewards as they face imminent pressures to contain the cost of rewarding employees.

Today, a notable challenge facing human resources practitioners is the challenge of attracting, retaining, motivating and developing talent (Deloitte, 2015). Unlike in the past where there were too many job seekers compared to available jobs, today, it is the opposite D'Amato and Herzfeld (2008. As organizations expand, focus should be on strategies that can attract and retain high-quality employees (Carrell, 1995) to match the increasing market demands. Tymon et al., (2011) noted that, retaining talented employees is paramount to business operations since they already have firm specific skills and their voluntary exits may impact negatively on the firm.

According to Armstrong (2007), employee benefits are "elements of remuneration given in addition to the various forms of cash pay and include items that are not strictly remuneration, such as annual holidays." Mamoria (2011) defines employee benefits as payments made to an employee by an employer in monetary or service form in addition to their salaries and are designed to attract and retain the best personnel. Employee benefits are classified into two categories, statutory and discretionary, according to Marsh and Kleiner (1998) and top employee management (2017). Statutory benefits are offered by an employer because they are required by law thus making it mandatory and they include social security, hospital insurance, work injury benefits, annual leave, sick leave and unemployment insurance. Discretionary benefits on the other hand are offered by an employer at their own free will and they include childcare benefits, private healthcare insurance, life assurance, payment for time not worked, disability insurance, flexi-time and paid leave.

Employers provide discretionary benefits as one of the strategies for cutting a niche for themselves as market leaders in attracting and retaining talent in the ever competitive and globalized economy. A positive expected behavior would be a highly motivated workforce, increased productivity, engagement, loyalty and retention. According to Employee Benefits Research Institute (2015), twenty two percent of workers accept, quit or change jobs because of benefits an employer offered or failed to offer. Simon and Hinkin (2001) notes that, appropriately designed and executed employee retention policies and strategies can increase retention. This study looked into work life balance, private healthcare insurance, wellness programs and pension plans as cited by Kwon (2013) as the components of employee 
discretionary benefits. The components have been chosen because of their uniqueness, the nature of work the population under study engage in and the fact that they do not have direct financial implication and are known to the target population.

Lazar, Osian and Ratiu (2010) defines work life balance (WLB) as initiatives established and supported by organizations to facilitate employees in performing their job assignments as well as dealing with their private concerns without compromising on either of them. According to Dunne (2007), most job seekers seek opportunities that allow them to integrate work and their individual lives. According to Fujimoto, Strybosch, Fitzpatrick and Hartel (2007) such support can be availed through part-time working, job sharing, flexibility of hours and home working, compressed work weeks, parental leave and on-site child care facility. A study by the UK's Equal Opportunities Commission as cited by Dunne (2007) found out that, employers that have failed to support WLB practices have in the recent times witnessed decreased employee retention rates.

Pension plans are types of differed income employees accrue during their active work life and are redeemable upon retirement (RBA, 2016). Evidence shows that, the lucrativeness of pension increase with age (Gough \& Hick, 2009). Older employees have the advantage of experience and this makes it imperative for the employer to ensure sufficient strategies of retaining them. A research in the United States as cited by Kleiner (2003) found out that good pension plans were the second ranked type of benefits by employees that influenced their decision on who is a preferred employer.

According to Oziminkowski (2008), wellness programmes are strategies initiated and supported by the employer to enhance the overall wellbeing of its employees. Such programmes, Ngeno and Muathe (2016), note, includes screening for risk factors that cause diseases, smoking cessation, counselling, fitness programs, weight loss and nutrition. According to Deloitte (2015) employers offer wellness programmes to promote employees' general health and boost recruitment and retention rates. The Economist Intelligence Unit's (EIU) survey in 2015 in the US revealed that, Organizations that offer wellness programs and having those programs easily within reach were likely to have the edge over their competitors in attracting and retaining employees.

Private healthcare insurance is an arrangement by employers to protect its employees in sickness. It allows employees to receive treatment up to their individual assigned limits by accredited service providers. This benefit is usually very attractive to many employees depending on how it is packaged and managed as it can save them unexpected costs resulting from sickness and ensures that they get the best available and affordable Medicare. It is a tool that can be used strategically for attracting and retaining employees. This type of insurance is different from the National Hospital Insurance Fund in which the premiums are met by individual employees. A research in the United States as cited by Kleiner (2003) found out that good private healthcare benefits were the second ranked type of benefits by employees that influenced their decision on who is a preferred employer.

\section{State Agencies in Kenya}

State Agencies in the Kenyan context are organizations established by Acts of Parliament as a body corporate to perform the functions specified under the specific Act: State Corporations Act, Chapter 446 (Constitution of Kenya 2010). According to SCAC (2018), Kenya has a total of 138 state agencies spread across the 20 government ministries with each ministry headed by a cabinet secretary. Some of the state agencies are fully funded by the government while others are partially funded. The National Treasury is one of the government ministries and has a total 
of fifteen state agencies four being regulators. Retention rates of key employees in the state agencies have been decreasing thus undermining effective and efficient service delivery. This situation could be attributed to insufficient employee commitment and retention policies (Njiru, 2008). Nyanjom (2013) further notes that, the mass exodus of employees in State agencies in Kenya is a result of the search for better terms and conditions of work. Kenya Airways for example lost its talented pilots and cabin crew to local and international competitors because of pay and working conditions (Nyanjom, 2013).

\section{Research Problem}

Retention of employees in state agencies has been cited as a big challenge (ROK 2010 \& SCAC 2013) that has continued to undermine effective and efficient service delivery to the public. Despite the several public sector reforms that have been undertaken to improve the performance of state agencies, the most critical of those reforms addressing the GOK's ability to attract and retain employees has not been met (Opisa, 2013). Deloitte (2015) notes that, there is a looming crisis in employee engagement and retention in Kenya and it is projected that the sector will continue to face retention challenges in the next five years. Anti-counterfeit Authority for example lost twenty employees between the period 2010-2014 (Bretta \& Were, 2014) and in 2013-2017 Competition Authority of Kenya and Capital Markets Authority lost twelve and fifteen key employees respectively. Regulatory agencies under the National Treasury have wide mandates with lean structures and are domiciled only in Nairobi. Failure to retain employees in these agencies has a great impact on their service delivery (SCAC, 2013), sustainable development and contribution towards Vision 2030 and also depletion of their budgets as a result of recruitment, training and other related costs.

Notwithstanding the above, state agencies have remained hooked to traditional approaches to retention including pay increment and bonuses which have become almost untenable with the imminent economic pressures and the role of the Salaries and Remuneration Commission. Further, as Herzberg et al., (1957) notes, such traditional approaches, which are mostly direct financial in nature, may not address retention issues as lack of money can cause dissatisfaction, its availability does not guarantee satisfaction. This is because direct financial benefits fulfil the extrinsic aspects of job motivation only. Intrinsic motivation, which can be achieved by administering discretionary and indirect financial benefits, have the potential of being used as effective tools of employee retention

\section{Study Objectives}

i) To determine the influence of private healthcare insurance on employee retention in regulatory state agencies under the National Treasury, Nairobi City County, Kenya.

ii) To establish the influence of work life balance on employee retention in regulatory state agencies under the National Treasury, Nairobi City County, Kenya.

iii) To find out the influence of wellness programs on employees retention in State Agencies under the National Treasury, Nairobi City County, Kenya.

iv) To assess the influence of pension plans on employee retention in regulatory state agencies under the National Treasury, Nairobi City County, Kenya.

\section{LITERATURE}

\section{Private Healthcare Insurance on Employee Retention}

Health is an important factor of labour in production (Grossman, 1972). Even with the right employees in terms of education, skills and experiences, their optimal productivity is dependent on their health status and that of their dependents. Frequent health issues may result to 
absenteeism which could be ameliorated by having in place a good private healthcare insurance that enable workers seek preventive care or seek healthcare attention in cases of illnesses, incidences or accidences. Absenteeism affects the performance of the employee and this has a direct impact on the general performance of an organization. Further, if an organization cannot provide standard healthcare to its employees, they may feel that the employer is not concerned with their social needs and that their efforts are not appreciated. This scenario may persuade them to find employment in other organizations who provide private healthcare insurance for its employees.

According to Rynes \& Gearhart (2000), to retain high quality employees, employers must provide good private healthcare insurance as a strategy. Failure to do so may lead to high levels of staff turnover. Anderson 1997; Monheit \& Cooper 1993; Bunchmueller 1996; Slade 1997 posits that, workers who work in organizations that provide good private healthcare insurance are less likely change jobs frequently compared to those who work in organizations without such a benefit. A 2014 survey by Deloitte on Global top five total reward priorities found out that, $43 \%$ of employers worldwide had recently put or are planning to put more emphasis on health and wellness as a package of the total reward for the sole purpose of attracting and retaining employees.

\section{Work Life Balance on Employee Retention}

Lazar, Osian and Ratiu (2010) defines work life balance (WLB) as initiatives established and supported by organizations to facilitate employees in performing their job assignments as well as dealing with their private concerns without compromising on either of them. Rife et al (2015) concurs to this definition noting that, WLB is the extent employees are able to meet their personal as well as work demands satisfactorily. There is therefore need for employers to embrace initiatives that facilitate harmony between personal an organizational needs of a worker (Walker, 2014). Hartel et al (2007) identifies key WLB initiatives part-time working, job sharing, flexibility of hours and home working, compressed work weeks, parental leave and onsite child care facility. The rise in importance of WLB has been attributed to more women taking up employment, the increase of single parents, the influx of Generation $Y$ in the workforce of today and progress in the use of technology or automation of processes at work, Lazer et al (2010). The ability of employees to integrate work and their personal life demands has been cited by several studies as a key retention factor. A study by Mbilinyi and Munga (2008) found a significant relationship between non-financial benefits and employee retention of health workers in Tanzania's health sector. The non-financial benefits under study were: leave, promotion, housing, training and safe and supportive work environment.

\section{Pension plans on Employee Retention}

Pension is an accrued benefit in the active working life of an employee and is designed to be utilized upon retirement. According to RBA (2016), there are four pension plans in Kenya; Defined Contribution and Defined Benefit, provident fund and pension fund. State Agencies in Kenya provide DC plan for its employees on Permanent and Pensionable terms of employment while those on contract enjoy gratuity compensation instead. This is as a result of the amendment of the Retirements Benefits Act that required employers to transit to offering DC pension as from 2011. Evidence show that, the lucrativeness or attractiveness of pension to employees rises with age (Gough \& Hick, 2009). Younger employees don't see the importance of pension because of the assumption that they are way too long to retiring. This may curtail employers from using pension provision to attract young people. However, pension provision is attractive to older employees and employers can capitalize on this factor to retain them. Older 
employees have the advantage of experience and this makes it imperative for the employer to ensure sufficient strategies of retaining them. A study by Taylor (2000) in the United Kingdom found a significant relationship between pension and employee retention. The study focused in three sectors of the economy and used descriptive research design and primary data obtained using questionnaires and interview methods. Taylor (202) indicated that pension plans significantly influence their decisions to stay.

\section{Wellness and Programs on Employee Retention}

Many research findings on health indicate that wellness of individuals' impact so much on their health. Lack of physical exercise for example has been linked with life style diseases such as cancer, diabetes and blood pressures among others. Employees, especially those who work in an office setting, are subjected to go about their daily business while seated and staring at a computer for long hours. On average, an employee spends eight hours daily in an office. This phenomenon is a risk to the health of employees which has the potential to directly affect not only the productivity of the employees but also their decision to stay with the organization as a healthy employee is a happy employee.

With improved overall health of an employee, and employer will definitely save a lot in terms of healthcare costs, absenteeism and productivity. According to 2015 surveys of Employers and Healthcare Consumers in the USA by Deloitte, it was found that, most employers offer wellness programmes to promote healthy lifestyles among its workforce and boost recruitment and retention rates (Deloitte, 2015). From the survey, it was noted that, $93 \%$ of the surveyed respondents (employers) agree or somewhat agree that employees expect them to offer wellness programs thus making it a very important recruitment and retention strategy. The survey carried out in the USA used online questionnaires to collect data from a sample of 700 employers sampled from different sectors of the economy with employees ranging from 50 2500.

\section{MATERIALS AND METHODS}

The study employed descriptive and cross sectional research designs. The target population were all the 320 employees of the four regulatory state agencies under the National Treasury, Kenya, as at $30^{\text {th }}$ June 2017. Stratified proportionate simple random sampling was used in selecting a sample size of 175 with top, middle level management and support staff used as strata. Quantitative and qualitative primary data was collected using self-administered semistructured questionnaires. The questionnaires returned were 145 which was $83 \%$ of the overall questionnaires. Validity was determined using factor analysis whereas reliability was determined using Cronbach's alpha coefficient. Data was analyzed using inferential statistics namely correlation analysis and multiple linear regression models. The findings of the study were presented using tables, graphs and pie charts.

\section{RESULTS}

\section{Correlation Analysis}

Table 1 Correlation Results

\begin{tabular}{|c|c|c|c|c|c|c|}
\hline Variable & Pearson r & 1 & 2 & 3 & 4 & 5 \\
\hline 1. Employee retention & r & 1 & & & & \\
\hline 2. Health insurance & $r$ & $.440 * *$ & 1 & & & \\
\hline 3. Wellness & $r$ & $.397 * *$ & -.038 & 1 & & \\
\hline
\end{tabular}




\begin{tabular}{lllllll} 
4. Work Life Balance & $\mathrm{r}$ & $.409 * *$ & $.312^{* *}$ & .09 & 1 & \\
5. Pension & $\mathrm{r}$ & $.165^{*}$ & $.391^{* *}$ & -.099 & $.331^{* *}$ & 1 \\
\hline
\end{tabular}

** Correlation is significant at the 0.05 level (2-tailed).

As shown in Table 1 employee retention is positively and significantly associated with private health insurance $(r=.440,=.000)$, wellness programs $(r=.397, p=.000)$, work life balance $(r=.409)$, and pension ( $r=.165)$. These findings aligns with that of Macey and Scneider, (2008) whose study cited by Kibui et al (2014) connotes that, high level of satisfaction is evidenced in the level of employee productivity and loyalty. The findings are also in tandem with that of Taylor (2000) in the United Kingdom who found a significant relationship between pension and employee retention.

\section{Regression Analysis}

Table 2 Model Summary

\begin{tabular}{lllll}
\hline Model & $\mathbf{R}$ & R Square & Adjusted R Square & Std. Error of the Estimate \\
\hline 1 & 0.652 & 0.425 & 0.408 & 0.51932 \\
\hline
\end{tabular}

As shown in Table 2, private health insurance, pension, wellness, and work life balance were found to be satisfactory variables in employee retention. This was supported by coefficient of determination also known as the $\mathrm{R}$ square of $65.2 \%$. This meant that health insurance, pension, wellness, job satisfaction, and work life balance explain $65.2 \%$ of the variations in the dependent variable which was employee retention. The results further meant that the model applied to link the relationship of the variables was satisfactory. Table 3 shows the analysis of variance results.

Table 3 ANOVA Results

\begin{tabular}{llrrrrrr}
\hline Model & & \multicolumn{1}{c}{ Sum } & of & df & Mean Square & F & Sig. \\
\hline 1 & Rquares & & & & & \\
& Regression & 27.897 & 4 & 6.974 & 25.860 & $\mathbf{0 . 0 0 0}$ \\
& Residual & 37.757 & 140 & 0.270 & & \\
& Total & $\mathbf{6 5 . 6 5 4}$ & $\mathbf{1 4 4}$ & & & \\
\hline
\end{tabular}

Table 3 presents the Analysis of Variance results which revealed that the overall model was statistically significant. Further, the results implied that the independent variables are good predictors of health services. This was supported by an F statistic of 25.860 and the reported $p$ value $(0.000)$ which was less than the conventional probability of 0.05 significance level.

Table 4 Regression Results

\begin{tabular}{lllll}
\hline \hline & B & Std. Error & t & Sig. \\
\hline (Constant) & 1.644 & 0.258 & 6.371 & $\mathbf{0 . 0 0 0}$ \\
Health insurance & 0.276 & 0.051 & 5.415 & $\mathbf{0 . 0 0 0}$ \\
Pension & -0.30 & 0.061 & -0.496 & $\mathbf{0 . 6 2 1}$ \\
Work life & 0.190 & 0.050 & 3.791 & $\mathbf{0 . 0 0 0}$ \\
Wellness & 0.244 & 0.041 & 5.908 & $\mathbf{0 . 0 0 0}$ \\
\hline
\end{tabular}


As shown in Table 4 health insurance and employee retention are positively and significantly related $(\beta=.276, p=.000)$. This is in line with the results by Rynes \& Gearhart (2000), who concluded that health health insurance is a very crucial factor for retaining employees. The results also revealed that work life balance is significantly and positively related to employee retention $(\beta=.190, p=.000)$ which is in line with the results of Lazer et al (2010) who indicated that work life balance motivates employees and improves their loyalty. Further, the results also revealed that wellness and employee retention are positively and significantly associated $(\beta=.244, p=.000)$. This is consistent with the results by Kihoro et al (2016) who found positive and significant relationship between wellness and employee loyalty. The results reveals negative and insignificant relationship ( $B=-.30, p=.621)$ between pension and employee retention.

\section{CONCLUSION}

The study conclude that health insurance is crucial for motivation, performance and contribution to intrinsic employee values which leads to employee loyalty. Health insurance packages helped the employees build trust with the management and feel that they are taken care and therefore, has more significant effect than pay increase which only contributes to the extrinsic values. Additionally, the study identified that wellness programs are crucial motivators for the employees. Wellness programs ensures that the employees are in good conditions for work and makes them feel good and confident which translates to employee loyalty. Moreover, work life programs involves how the work period of the employees is distributed. The study noted that allowance to concentrate on other things in life and not overburdening the employees with work life, significantly improves the relationship between the employees and the organization hence contributing in employee retention. The study noted that there is insignificant relationship between pension plans and employee retention. This can be explained through perspective that most of the employees are young and are less likely to think about life at old age. Additionally, most of the employees have retirement plans which affects their disposition on pension.

\section{Areas for Further Research and recommendations}

State agencies need to consider their human resource policies and how they affect the motivation and loyalty of the employees. The agencies need to identify the best programs which brings good balance of intrinsic value and extrinsic values. Benefits and compensation packages should be crafted in a manner that is comparative and based on the employee needs so that it attracts the right personnel to remain in the organization. State agencies human resources therefore, are encouraged to craft strategies that can lower the attrition rates. The management can strike a balancing policies between the identified factors of employee retention which will improve the relations with employees and subsequently increase their loyalty, commitment and motivation. More importantly, the agencies should create a total reward structure comprising of financial packages, benefits, bonuses and others which should be all tied to the overall objective of the organization. The practice or use of policies based on different reward structures, rewards, benefits and recognitions plan should all be set out to reflect the value of the employee.

\section{REFERENCES}

Carrell, M.R. (1995). Human Resource Management: Global strategies for managing a diverse workforce,5th Edition, Prentice: Hall New Jersey.

Chiang, F.F., \& Birtch. T.A., (2011). The performance implications of financial and non-financial rewards: An Asian Nordic comparison. Journal of Management Studies, 49, 538-570. 
Cooper, P. F., \& Monheit, A. C., (1993). Does Employment-Related Health Insurance Inhibit Job Mobility? Inquiry 30 (4), 400-416.

Deloitte (2015). 2014 Global Top Five Rewards Priorities Survey. www.deloitte.com

Dunne, H., (2007). Putting balance into business: Work/life balance as a business strategy for avoiding brain drain. Strategic HR Review. 6, 28 - 3.

Gough, O., \& Hick, R., (2009). Employee Evaluations of Occupational Pensions. Employee Relations. 31(2), 158-167.

Hartel, C., Fujimoto, Y., Strybosch, V., Fitzpatrick, K. (2007). Human Resource Management: Transferring Theory into Innovative Practice. Pearson Education Australia.

Herzberg, F., (1968). Work and the Nature of Man. World Publishing. New York, NY.

Kibui, A. W., Gachunga, H., \& Namusonge, G.S., (2014). Role of Talent Management on Employees Retention in Kenya: A Survey of State Corporations in Kenya: Empirical Review. International Journal of Science and Research. 3, 414- 424.

Kihoro, P. M., Waiganjo, E. W., Mungania, A. K. (2016). Influence of wellness programs on organizational performance in the banking industry in Kenya. International journal of academic research in business and social sciences. 6(7), 173 - 187.

Kwon, J., (2013). Employee Benefits in a Total Rewards Framework. International Society of Certified Employee Benefit Specialists. 1(1), 32 - 39.

Lazar, I., Osoian, C., Ratiu., P. (2010). The role of work life balance practices in order to improve organizational performance. European research studies. XIII (I)

Lazar, I., Osoian, C., \& Ratiu, P. (2010). The Role of Work-Life Balance Practices in Order to Improve Organizational Performance. European Research Studies. XIII (1).

Nyaga, J. W., (2015). Non-Financial Reward and Employee Retention in Private Primary Schools in Kenya (Kiambu County). International Journal of Management and Commerce Innovations. 3, 240-254.

Nyanjom, C.R. (2013). Factors affecting employee retention in the state corporation in Kenyan. Unpublished MBA thesis, University of Nairobi

Rife, A.A., Hamilton, B. A., \& Hall, J. R., (2015). Work Life Balance. Industrial and Organizational Psychology.

Simons, T. \& Hinkin, T., (2001). The effect of employee turnover on hotel profits. Cornell Hotel and Restaurant Administration Quarterly. 42, 65-9.

Taylor, S., (2000). Occupational pensions and employee retention. Employee Relations. 22 (3), $246-259$.

Walker, D.,(2014). Employee benefits are the norm, but using them is not. Strategic HR Review. 13(6), $255-259$.

Whitaker, P. (2010). What non-financial rewards are successful motivators? Leading industry experts answer your strategic queries. Strategic HR Review. 9, 43-44. 